EL DINAR: Jurnal Keuangan dan Perbankan Syariah

Volume 9, No. 2, Tahun 2021

E ISSN: 2622-0083

\title{
INDEKS MAQASHID SYARIAH DAN NILAI PERUSAHAAN BANK UMUM SYARIAH
}

\author{
Rida Almiravalda Hidayat ${ }^{1}$, Usman ${ }^{2}$ \\ 1,2 Fakultas Ekonomi dan Bisnis, Universitas Dian Nuswantoro \\ Jalan Nakula 1 No. 5-11, Semarang, Jawa Tengah, 50131, Indonesia
}

区 Corresponding Author:

Nama Penulis: Usman

E-mail: usman@dsn.dinus.ac.id

\begin{abstract}
Islamic banks require a different performance measurement than a conventional bank to keep their sustainability. The main disadvantage of employing conventional benchmarks to measure Islamic bank performance is that they fail to investigate shariah facets. This study aims to discover how maqashid shariah index using IMSPM (Integrated Maqashid al-Shariah based Performance Measure) approach and firm value using EVA (Economic Value Added) approach and examine its impact with capital structure on the corporate values of Islamic bank. This study using a quantitative method with the purposive sampling technique. This study involved 11 Islamic bank's annual reports listed in the Bank Indonesia and OJK from 2015 to 2019 period. The analysis method is multiple linear regression using Eviews 10 program. This study finds that the sample performed highest on the objective of nafs (self) over five-year period. The companies with a constant NOPAT and IC have a better EVA. Maqashid Syariah Index positively influence firm value while the capital structure has no effect.
\end{abstract}

Keywords: Maqashid Sharia Index; IMSPM; Firm Value; EVA; Capital Structure

Abstrak
Perbankan syariah memerlukan pengukuran performa yang berbeda
dengan bank umum untuk mempertahankan keberlangsungan
hidupnya. Hal ini perlu dilakukan karena pengukuran kinerja
konvensional gagal menjelaskan faktor-faktor syariah yang ada di dalam
perbankan syariah. Penelitian ini bertujuan untuk mengetahui
bagaimana Indeks Maqashid Syariah diukur menggunakan Integrated
Maqashid al-Shariah based Performance Measure (IMSPM) dan nilai
perusahaan melalui Economic Value Added (EVA) pada bank umum
syariah mencari tahu pengaruh dari Indeks Maqashid Syariah dan
struktur modal terhadap nilai perusahaan bank umum syariah.
Penelitian ini menggunakan metode kuantitatif dengan teknik
pengambilan sampel purposive sampling. Data yang digunakan adalah 
data sekunder dari laporan tahunan 11 bank sampel yang terdaftar di Bank Indonesia dan OJK selama 2015-2019. Metode analisis yang digunakan adalah regresi linier berganda dengan bantuan software EViews 10. Hasil penelitian menunjukkan bahwa Indeks Maqashid Syariah paling tinggi selama 5 tahun ditunjukkan oleh objek nafs (self). Perusahaan dengan NOPAT dan IC yang stabil mempunyai EVA yang lebih baik. Indeks Maqashid Syariah berpengaruh positif signifikan terhadap nilai perusahaan sedangkan struktur modal tidak berpengaruh. Kenaikan pada nilai Indeks Maqashid Syariah akan memberikan dampak yang baik pada nilai perusahaan perbankan syariah di Indonesia.

Kata kunci: Indeks Maqashid Syariah; IMSPM; Nilai Perusahaan; EVA; Struktur Modal

\section{PENDAHULUAN}

Perbankan syariah mengalami perkembangan yang cukup pesat dengan pertumbuhan mencapai 10\% per tahun sehingga mendorong kompetisi yang lebih ketat terhadap bank konvensional (Otoritas Jasa Keuangan, 2020). Hingga awal tahun 2020 jumlah bank syariah di Indonesia mencapai 189 bank yang terdiri dari 164 Bank Pembiayaan Rakyat Syariah (BPRS), 20 Unit Usaha Syariah (UUS), dan 14 Bank Umum Syariah (BUS) (OJK, 2020).

Pengukuran performa bank syariah masih menjadi perdebatan karena dalam beberapa penelitian terdahulu bank syariah memiliki performa yang jauh lebih rendah jika dibandingkan dengan bank konvensional (Analia \& Anto, 2019; Antonio et al., 2012; Haniffa \& Hudaib, 2007; Hidayat et al., 2019; Rosanti, 2019). Hal ini terjadi karena tujuan bank syariah banyak memasukan faktor-faktor syariah didalamnya seingga metode perbandingan konvensional tidak dapat menjelaskan tentang aspek syariah didalam perbankan syariah. Dalam mengukur kinerja perbankan syariah tidak didominasi oleh penggunaan rasio keuangan saja. Hal ini karena perubahan paradigma pada konsep indikator kinerja yang sering disebut Triple Bottom Lines meliputi ekonomi, lingkungan dan indikator sosial (Antonio et al., 2012).

Konsep maqashid syariah yang disampaikan oleh Ibn Qayyim Al-Jaziyah yaitu basis syariah memberikan manfaat terhadap sosial sesuai dengan konsep Triple Bottom Lines (Jauziyah, 1973). Konsep perhitungan performa bank syariah sudah mulai dikembangkan mulai dari konsep Islamic Disclosure Index (IDI) dan Islamic Quantitative Index (IQI), Ethical Identity Index (EII) (Haniffa \& Hudaib, 2007), Maqasid al-Shariah index (MSI) (Mohammed et al., 2008), serta penggabungan dari pendekatan finansial dan syariah Integrated Maqasid Al-Shariah Based Performace Measure (IMSPM) (Hudaefi \& Noordin, 
2019). Penerapan indeks maqasid syariah dapat menunjukan performa perbankan syariah dari konsep syariah dan finansial secara komprehensif.

Abdullah Ibn Bayyah menyatakan terdapat lima hal pokok (dharuriyah) yang tercantum dalam maqashid syariah yaitu menjaga agama (khifdu din), menjaga nafsu (khifdu nafs), menjaga akal (khifdu aql), menjaga keturunan (khifdu nasl) dan menjaga harta (khifdu mal) (Nizar, 2016). IMSPM yang dikaji oleh Hudaefi \& Noordin (2019) merupakan pengembangan lebih lanjut untuk menghitung perfoma perusahaan dari segi agama dan keuangan secara komprehensif. Pengembangan IMSPM didasarkan pada ketidakmampuan pengukuran konvensional dalam menjelaskan aspek syariah pada perbankan syariah serta penelitian terdahulu tentang indeks maqashid syariah yang belum mencakup perhitungan konvesional seperti profitabilitas dan efisiensi dimana hal ini penting untuk mengetahui kinerja keuangan bank. Tabel 1 menunukkan konsep dari IMSPM.

Di sisi lain, tujuan berdirinya suatu perusahaan menurut Harjito \& Martono (2012) ada tiga, yang pertama untuk memperoleh keuntungan sebesar-besarnya, kedua menguntungkan pemegang saham serta pemilik perusahaan, dan yang terakhir adalah untuk menciptakan nilai perusahaan. Perbankan syariah memang tidak berfokus pada pencapaian profit yang tinggi dan keuntungan stakeholder, namun kedua hal tersebut mendukung besarnya nilai perusahaan. Nilai perusahaan merujuk pada nilai pasar suatu perusahaan yang biasanya direfleksikan dalam bursa saham. Hal ini berarti nilai perusahaan berpengaruh terhadap kepercayaan nasabah dan shareholder dalam mengambil keputusan investasi, kredit maupun aktivitas perbankan lainnya. Salah satu alat yang paling sesuai untuk mengukur nilai perusahaan pada perbankan syariah adalah Economic Value Added (EVA) (Panigrahi, 2017). Metode ini dapat menunjukan kesehatan keuangan perusahaan untuk mengetahui bagaimana nilai perusahaan di masa kini dan masa yang akan dating (Padli \& Diana, 2019; Rohmah et al., 2019).

Penelitan yang sudah dilakukan oleh Antonio et al., (2012), Mohammed \& Taib (2015) dan Mifrahi \& Fakhrunnas (2018) menganalsis peforma bank syariah menggunakan MSI, Performance Measures based on Maqasid al-Shariah framework (PMMS), dan Maqasid based Performance Evaluation Model (MPEM). PMMS dan MPEM merupakan bentuk pengembangan MSI. Dari ketiga contoh penelitian terdahulu, konteks yang digunakan semuanya masih menggunakan konsep Abu Zahrah dan penetapan rasio kinerjanya masih belum dapat mencakup perhitungan performa bank konvensional. Oleh sebab itu dalam penelitian kali ini peneliti memilih untuk menggunakan IMSPM yang sudah melakukan 
harmonisasi pengukuran yang mencakup konsep agama dan keuangan untuk mengukur performa perbankan syariah. Selain itu, penelitian sebelumnya belum melakukan perbandingan hasil perfoma indeks maqashid syariah dan performa keuangan konvensional serta pengaruhnya terhadap keputusan shareholder ataupun stakeholder.

Penelitian lain yang dilakukan oleh Rohmah et al. (2019) menghasilkan kesimpulan yang berbeda. Peneliti tersebut menggunakan MSI untuk menganalisis Maqashid Syariah Index dan sudah menyertakan variabel lain (ukuran perusahaan dan profitabilitas) sebagai pembanding pengukuran kinerja perusahaan terhadap nilai perusahaan. Hasilnya adalah indeks maqashid syariah tidak berpengaruh terhadap nilai perusahaan sedangkan variabel lain berpengaruh. Hasil tersebut tidak sejalan dengan penelitian yang dilakukan oleh Wahyuni et al., (2020) yang menunjukan bahwa Maqashid Syariah Index berpengaruh signifikan terhadap nilai perusahaan. Dari penelitian ini semuanya masih menggunakan MSI dan pengukuran kinerja perusahaan secara umum baru diproyeksikan melalui ukuran perusahaan dan profitabilitas.

Dalam meningkatkan nilai perusahaan, suatu perusahaan membutuhkan investasi proyek yang menguntungkan baik investasi eksternal (hutang dan bagi hasil) dan internal (laba ditahan dan saham). Sumber dana merupakan komposisi dari struktur modal perusahaan. Groth \& Anderson (1997) menyatakan bahwa komposisi struktur modal yang efisien dapat menurunkan beban modal. Turunnya beban dapat meningkatkan pengembalian dan mengembangkan nilai perusahaan.

Pada penelitian tentang pengaruh struktur modal terhadap nilai perusahaan oleh Antwi et al. (2012), Ananda (2017), Saifi et al. (2020) memberikan hasil bahwa terdapat pengaruh yang signifikan antara struktur modal dan nilai perusahaan. Namun berbeda dengan hasil penelitian dengan topik yang sama oleh Gupta \& Gupta (2014), Lestari (2017), Khanh et al., (2020) yang menunjukan bahwa struktur modal tidak mempunyai pengaruh yang signifikan terhadap nilai perusahaan.

Latar belakang tersebut menunjukan bahwa perbankan syariah memerlukan pengukuran performa yang berbeda dengan bank umum untuk mempertahankan keberlangusngan hidupnya. Hal ini harus dilakukan karena pengukuran kinerja konvensional gagal menjelaskan faktor-faktor syariah dalam perbankan syariah. 
Rida Almiravalda Hidayat: Indeks Maqashid Syariah Dan Nilai Perusahaan

Tabel 1. Konsep, Dimensi, dan Elemen Metode IMSPM

\begin{tabular}{|c|c|c|c|}
\hline \multicolumn{2}{|c|}{ Konsep (C) } & \multirow{2}{*}{$\begin{array}{l}\text { Dimensi (D) } \\
\text { D1. Non-negative } \\
\text { elements }\end{array}$} & \multirow{2}{*}{$\begin{array}{c}\text { Elemen (E) } \\
\text { E1. Interest free-produc }\end{array}$} \\
\hline $\begin{array}{l}\text { Maqashid } \\
\text { syariah }\end{array}$ & $\begin{array}{l}\text { Faith } \\
\text { (din) }\end{array}$ & & \\
\hline & & $\begin{array}{l}\text { D2. Creating awareness } \\
\text { of Islami banking }\end{array}$ & E2. Publicity \\
\hline & \multirow{4}{*}{$\begin{array}{l}\text { Self } \\
(\text { nafs })\end{array}$} & \multirow[b]{2}{*}{ D3. Justice } & E3. Charity \\
\hline & & & E4. Employee welfare \\
\hline & & D4. Removal of proverty & E5. Zakat fund \\
\hline & & D5. Job opportunities & 6. Total no. of branch \\
\hline & \multirow{3}{*}{$\begin{array}{l}\text { Intellect } \\
\text { ('aql) }\end{array}$} & D6. Education & E7. Eduation grant \\
\hline & & & \\
\hline & & D7. Reseacrh & E8. Research expense \\
\hline & \multirow{2}{*}{$\begin{array}{l}\text { Posterity } \\
\text { (nasl) }\end{array}$} & D8. Health environment & $\begin{array}{l}\text { E9. Agricultural } \\
\text { financing }\end{array}$ \\
\hline & & D9. Moral Development & E10. Training \\
\hline & \multirow{8}{*}{$\begin{array}{l}\text { Wealth } \\
\text { (mal) }\end{array}$} & $\begin{array}{l}\text { D10. Affordable products } \\
\text { and services }\end{array}$ & $\begin{array}{l}\text { E11. Non-performing } \\
\text { financing (loan) } \\
(\mathrm{NPF}(\mathrm{L}))\end{array}$ \\
\hline & & \multirow{2}{*}{ D11. Profit sharing ratios } & $\begin{array}{l}\text { E12. Mudarabah } \\
\text { financing }\end{array}$ \\
\hline & & & $\begin{array}{l}\text { E13. Musyarakah } \\
\text { financing }\end{array}$ \\
\hline & & \multirow{2}{*}{$\begin{array}{l}\text { D12. Restrutured } \\
\text { financing }\end{array}$} & $\begin{array}{l}\text { E14. Restructured } \\
\text { mudarabah financing }\end{array}$ \\
\hline & & & $\begin{array}{l}\text { E15. Restructured } \\
\text { musyarakah financing }\end{array}$ \\
\hline & & \multirow{2}{*}{ D13. Earning ability } & $\begin{array}{l}\text { E16. Return on Asset } \\
\text { (ROA) }\end{array}$ \\
\hline & & & $\begin{array}{l}\text { E17. Return on Equity } \\
\text { (ROE) }\end{array}$ \\
\hline & & $\begin{array}{l}\text { D14. Management } \\
\text { quality }\end{array}$ & $\begin{array}{l}\text { E18. Operational } \\
\text { efficiency }\end{array}$ \\
\hline
\end{tabular}

Sumber: (Hudaefi \& Noordin, 2019)

Alat ukur kinerja perbankan syariah juga perlu untuk selalu berkembang agar semakin akurat serta dapat menyajikan hasil terbaru dari 
kondisi yang ada dilapangan. Selain itu, diperlukan perbandingan bagaimana perfoma bank syariah dari faktor syari dan faktor keuangan konvensional serta pengaruhnya terhadap kondisi perusahaan baik dari sisi shareholder maupun stakeholder. Penelitian ini ditujukan untuk mengetahui bagaimana indeks maqashid syariah dengan metode pengembangan terbaru yang sudah menggabungkan aspek agama dan konvensional secara komprehensif, mencari tahu apakah perusahaan dengan maqashid syariah yang baik juga memiliki nilai perusahaan yang baik melalui Economic Value Added (EVA), serta melakukan perbandingan kinerja perbankan syariah dari segi maqashid syariah dan struktur modal terhadap nilai perusahaan.

\section{KAJIAN PUSTAKA}

\section{Indeks Maqashid Syariah}

Secara umum, preferensi diartikan sebagai pilihan suka atau tidak suka oleh seseorang terhadap suatu produk barang atau jasa yang digunakan. Kotler dalam Srikandi (2017) berpendapat bahwa preferensi konsumen menunjukkan kesukaan konsumen dari berbagai pilihan produk dan atau jasa yang ada. Preferensi konsumen dapat diketahui dengan mengukur tingkat kegunaan dan nilai relatif penting setiap atribut yang terdapat pada suatu produk atau jasa.

\section{Nilai Perusahaan}

Nilai perusahaan dalam pandangan klasik didefinisikan sebagai kepercayaan yang membantu perusahaan untuk menentukan pilihan yang ada atau secara teknis merupakan bobot yang dipertimbangkan oleh pembuat keputusan diperusahaan untuk mendapatkan tujuan-tujuan alternatif ketika hendak mengambil tindakan (Silalahi et al., 2020). Naiknya harga saham menjadi salah satu pengaruh positif ketika perusahaan dapat menciptakan nilai perusahaan dimana nilai ini adalah cerminan kesejahteraan para pemegang saham. Nilai perusahaan menunjukan nilai sekarang dari akumulasi penciptaan nilai yang dilakukan oleh perusahaan tersebut selama umur beroperasinya.

Economic Value Added (EVA) merupakah salah satu metode untuk mengukur nilai perusahaan dimana EVA adalah indikasi nilai perusahaan atas suatu investasi. Secara singkat, EVA adalah perbedaan pengembalian modal perusahaan (return on the company capital) dengan biaya modal (cost of capital). Sebagian pemegang saham sangat memperhatikan keuntungan ketika berinvestasi didalam sebuah perusahaan sehingga pihak manajemen seringkali dituntut untuk memberikan solusi dengan spesifik, oleh karena itu 
penggunaan EVA pada dasarnya untuk memaksimalkan nilai yang ingin dicapai oleh para pemegang saham. Hal ini karena EVA dapat menggunakan laporan akuntansi yang seringkali hanya menampilkan data histori menjadi data yang bernilai ekonomis .

\section{Struktur Modal}

Struktur modal merupakan pembiayaan permanen baik dari modal pemegang saham, saham preferen, dan hutang jangka panjang. Dalam sistem pendanaanya, struktur modal dibedakan menjadi dua yaitu pendaan internal (modal milik sendiri atau equity finaning) yang biasanya diperoleh melalui laba ditahan atau penerbitan saham dan pendanaan eksternal (pendanaan hutang atau debt financing) diperoleh melalui hutang (Lestari, 2017).

Didalam bisnis perbankan tingkat kecukupan modal menjadi hal yang sangat diperhatikan oleh perusahaan. Konsep struktur modal pada bank syariah ditunjukan dengan rasio tertentu yang disebut rasio kecukupan modal atau Capital Adequacy Ratio (CAR) dimana struktur modal adalah perbandingan antara modal sendiri dengan Aktiva Tertimbang Menurut Risiko (ARMR) (Istiqamah \& Supriyanto, 2017).

Dari penelitian yang dilakukan oleh Antwi et al. (2012), pengambilan keputusan dalam struktur modal mempunyai banyak efek yang salah satunya adalah berpengaruh terhadap nilai perushaaan. Mereka merekomendasikan untuk selalu membandingkan keuntungan marginal penggunaan hutang jangka panjang pada biaya marginal hutang jangka panjang sebelum melakukan operasi keuangan. Hal ini sesuai dengan hasil temuan bahwa hutang jangka panjang secara positif berpengaruh pada nilai perusahaan seperti modal ekuitas. Penelitian ini juga sejalan dengan Ananda (2017) yang menyatakan bahwa struktur modal berpengaruh positif signifikan terhadap nilai perusahaan. Hal ini berarti struktur pendanaan di dalam perusahaan dengan proporsi hutang semakin besar maka nilai perusahaanya juga makin besar. Begitu pula hasil penelitian yang dilakukan oleh Saifi et al. (2020) pada perusahaan manufaktur yang terdaftar di Bursa Efek Indonesia. Mereka menggunakan laba ditahan untuk mendanai aktivitas operasional dan struktur modal secara signifikan berpengaruh secara negatif terhadap nilai perusahaan.

\section{HIPOTESIS}

\section{Hubungan Indeks Maqashid Syariah dan Nilai Perusahaan}

Dalam tujuan jangka panjang, tujuan utama perusahaan adalah memaksimalkan nilai perusahaan demi kesejahteraan para shareholder 
(Wahyuni et al., 2020). Nilai perusahaan sendiri memberikan peranan penting dalam pandangan para pemegang saham untuk terus berinvestasi dan calon pemegang saham untuk mau berinvestasi mengingat nilai pasar yang tergambar di pasar bursa merupakan refleksi dari nilai perusahaan itu sendiri.

Performa perusahaan merupakan gambaran level yang telah dicapai oleh perusahaan dalam mewujudkan tujuan perusahaan, visi, dan misi sesuai dengan perencanaan strategik perusahaan. Penilaian performa bank syariah tidak hanya dinilai dari segi finansial saja, namun perlu pendekan nonfinansial yang mengarah pada prinsip-prinsip syariah oleh karena itu Indeks maqashid syariah menjadi salah satu alat ukur performa keuangan syariah (Mohammed et al., 2008).

Perusahaan dengan performa yang baik akan meningkatkan harga saham di pasar bursa yang berefek pada naiknya nilai perusahaan. Penelitian yang dilakukan oleh Wahyuni et al. (2020) menunjukan bahwa indeks maqashid syariah memiliki pengaruh positif terhadap nilai perusahaan. Begitu juga menurut Efendi \& Wibowo (2017), kinerja perusahaan yang baik merefleksikan nilai perusahaan yang bagus sehingga para investor cenderung tertarik untuk melakukan pembelian saham. Berdasarkan literatur tersebut dapat diperoleh hipotesis pertama yaitu:

H1: Indeks maqashid syariah berpengaruh prositif terhadap nilai perusahaan bank umum syariah

\section{Hubungan Struktur Modal dan Nilai Perusahaan}

Struktur modal berkaitan dengan sumber pendanaan perusahaan baik sumber internal maupun eksternal dimana sumber internal diperoleh melalui laba ditahan dan sumber eksternal berasal dari investor atau kreditur (Saifi et al., 2020). Sriram (1978) menyatakan bahwa sturktur modal merupakan proporsi penggunaan hutang. Modigliani \& Miller (1958) menjelaskan bahwa aktifitas keuangan dengan menggunakan hutang mempengaruhi nilai perusahaan, walaupun didalamnya akan terjadi kenaikan pajak dari pembayaran bunga hutang. Harris \& Raviv (1979) melakukan uji literatur yang berfokus pada hal-hal yang mempengaruhi kebijakan keuangan dan struktur modal. Selanjutnya mereka mengklasifikasikan berdasarkan pajak, biaya kebangkrutan, biaya agensi, asimetri informasi, interaksi dengan produk atau masukan dan pertimbangan kontrol perusahaan. Sanders (1998) dalam Ogbulu \& Emeni (2012) melakukan pendekatan yang berbeda dan mengklasifikasikan teori struktur modal menjadi beberapa kelompok. Kelompok teori yang mendukung 
optimalisasi hutang merujuk pada TOT, kelompok pengoptimalan hirarki keuangan yang mengarah pada pecking order theory dan teroi MM tentang tidak relevannya struktur modal terhadap nilai perusahaan.

Di dalam bisnis perbankan tingkat kecukupan modal menjadi hal yang sangat diperhatikan oleh perusahaan. Konsep struktur modal pada bank syariah ditunjukan dengan rasio tertentu yang disebut rasio kecukupan modal atau Capital Adequacy Ratio (CAR) dimana struktur modal adalah perbandingan antara modal sendiri dengan Aktiva Tertimbang Menurut Risiko (ARMR) (Istiqomah \& Supriyanto, 2017). Dimana tujuan perusahaan adalah untuk memaksimalkan profit dan meningkatakn nilai perusahaan melalui struktur modal. Saifi et al. (2020) menemukan bahwa perusahaan lebih memilih untuk menggunakan pendanaan internal daripada pendanaan eksternal karena pembayaran bunga dari hutang akan mengurangi pendapatan dan menurunkan profitabilitas.

Khanh et al. (2020) menemukan bahwa sturktur modal mempunyai pengaruh nonlinier terhadap nilai perusahaan dimana kesalahan dalam pengambilan hutang perusahaan akan mengurangi nilai perusahaan bahkan menyebabkan kebangkrutan. Begitupun peneltian yang dilakukan Gupta \& Gupta (2014) yang menunjukan adanya hubungan negatif signifikan dalam sturktur modal dan nilai perusahaan. Dari literatur tersebut, dapat diperoleh hipotesis kedua yaitu:

H2: struktur modal berpengaruh negatif terhadap nilai perusahaan bank umum syariah

\section{METODE}

Penelitian ini menggunakan indeks maqashid syariah sebagai variabel independen pertama (X1) yang diproyeksikan oleh IMSPM, kajian dari Hudaefi \& Noordin (2019) yang menguraikan karakteristik observasi melalui metode sekaran dengan memasukan kedalam model pengukuran dan pembebanan bobot berdasarkan konsep keseimbangan. Dari uraian karakteristik tersebut, selanjutnya data dimasukan dalam rumus dari tiaptiap indikator sesuai formula yang ada didalam IMSPM dengan rumus utama yang tertulis pada persamaan (1). Variabel independen yang kedua adalah struktur modal yang akan diukur dengan CAR, dengan formula CAR tertulis pada persamaan (2). Nilai perusahaan sebagai variabel terikat diukur dengan Economy Value Added (EVA) dari perbankan syariah dengan formula yang tertulis pada persamaan (3). 
Rida Almiravalda Hidayat: Indeks Maqashid Syariah Dan Nilai Perusahaan

$$
\begin{aligned}
& \text { IMSPM = PI(O1) + PI(O2) + PI(O3) + PI(O4) +PI(O5) } \\
& \text { CAR = (Modal Bank /Aktiva Tertimbang Menurut Risiko }) \times 100 \% \\
& \text { EVA = NOPAT - (WACC x IC) }
\end{aligned}
$$

Keterangan:

$\begin{array}{ll}\text { IMSPM } & : \text { Integrated Maqashid al-Shariah based Performance Measure } \\ \text { PI } & : \text { Performance Indicator } \\ \text { O1, 02, 03, 04, 05: Indicator of Maqashid al-Shariah } \\ \text { CAR } & : \text { Current Asset Ratio } \\ \text { EVA } & : \text { Economy Value Added } \\ \text { NOPAT } & : \text { Net Operating Profits After Tax } \\ \text { WACC } & : \text { Weighted Average Cost of Capital } \\ \text { IC } & : \text { Invested Capital }\end{array}$

Terdapat 14 Bank Umum Syariah yang terdaftar dalam BI sampai dengan tahun 2020, dengan teknik pengambilan sampel purposive sampling menggunakan beberapa kriteria yang sudah ditetapkan sehingga jumlah objek sampel penelitian ini adalah 11 BUS selama 5 tahun sejak 2015-2019 dengan total ukuran sampel yang direncanakan 55 item. Data yang digunakan dalam penelitian ini adalah data sekunder yang diperoleh dari laporan keuangan tahunan (annual report) Bank Umum Syariah yang terdaftar pada Bank Indonesia. Tabel 2 menunjukkan bank yang menjadi sampel dalam penelitian ini.

Untuk mencari tahu apakah indeks maqashid syariah dan struktur modal memiliki pengaruh terhadap nilai perusahaan, penelitian ini menggunakan regresi linier berganda melalui program Eviews 10. Setelah mendapat hasil model regresi dilakukan pemeriksaan terhadap pemenuhan asumsi klasik, menilai GoF model regresi, dan menguji parameter model individual.

Tabel 2. Sampel Bank Umum Syariah

\begin{tabular}{cl}
\hline No. & \multicolumn{1}{c}{ NAMA BANK SYARIAH UMUM } \\
\hline 1 & PT. BANK MUAMALAT INDONESIA \\
\hline 2 & PT. BANK VICTORIA SYARIAH \\
\hline 3 & PT. BANK BRI SYARIAH \\
\hline 4 & PT. BANK JABAR BANTEN SYARIAH \\
\hline 5 & PT. BANK BNI SYARIAH \\
\hline 6 & PT. BANK SYARIAH MANDIRI \\
\hline 7 & PT. BANK MEGA SYARIAH \\
\hline 8 & PT. BANK PANIN DUBAI SYARIAH \\
\hline 9 & PT. BANK SYARIAH BUKOPIN \\
\hline 10 & PT. BCA SYARIAH \\
\hline 11 & PT. BTPN SYARIAH \\
\hline
\end{tabular}

Sumber: Data diolah Peneliti (2020) 


\section{HASIL DAN PEMBAHASAN}

Berdasarkan laporan tahunan dari 11 Bank Umum Syariah yang memenuhi kriteria dari purposive sampling diperoleh ukuran sampel sebanyak 55 item. Dilakukan pengukuran terhadap seluruh sampel untuk mendapatkan hasil Indeks Maqashid Syariah, Nilai Perusahaan, dan Struktur Modal yang selanjutnya dilakukan olah data dengan software Eviews 10.

\section{Indeks Maqashid Syariah}

Indeks Maqashid Syariah dihitung menggunakan metode IMSPM dengan beberapa tahapan sesuai prosedur. Tabel 3 menunjukkan hasil akhir perhitungan IMSPM Bank Umum Syariah tahun 2015-2019. Jika dilihat pada hasil keseluruhan, terdapat beberapa angka 0 pada kolom tabel yang berarti data untuk langkah awal analisis IMSPM tidak tersedia pada laporan keuangan tahunan dari bank terkait. Namun, ada dua bank yang mempunyai keseluruhan data yang dibutuhkan dalam analisis IMSPM yaitu Bank BNI Syariah dan Bank Syariah Mandiri serta Bank BTPN Syariah sebagai bank yang kelengkapan datanya paling minim.

Dari IMSPM selama 5 tahun, nilai IMSPM tertinggi adalah 0,89 dan terendah 0,07 dimana 89\% berasal dari Bank Syariah Mandiri dan 7\% dari Bank Panin Syariah. Secara umum dari rata-rata selama 5 tahun Bank Mandiri memiliki rata-rata tertinggi dengan perolehan 0,40 disusul oleh Bank BNI Syariah sebesar 0,28 dan yang paling rendah adalah Bank Jabar Banten Syariah sebesar 0,20. Dari hasil ini dapat diambil kesimpulan bahwa bank dengan laporan keuangan yang lengkap dapat memberikan performa IMSPM lebih baik, sedangkan bank dengan laporan keuangan yang paling tidak lengkap belum tentu performanya paling buruk.

Performa secara umum untuk tiap konsep dapat dilihat dari rata-rata secara keseluruhan dari masing-masing PI (Performance Indicator) dan total PI. Rata-rata keseluruhan PI menunjukan jumlah rata-rata PI selama 5 tahun dari tiap sampel sedangkan total PI merupakan jumlah PI dari setiap sampel pada setiap konsep. Dari rata-rata PI, objek paling tinggi adalah self $(1,367)$ disusul oleh faith $(1,046)$, wealth $(0,417)$, posterity $(0,037)$, dan terakhir intellect $(0,003)$. Artinya dari semua sampel objek paling tinggi selama 5 tahun adalah self (nafs), hal ini sejalan dengan hasil penelitian yang dilakukan oleh Hudaefi \& Noordin (2019).

Pada objek faith (din), sampel yang menunjukan proporsi PI paling tinggi adalah Bank Jabar Banten Syariah dengan perolehan rata-rata PI (01) selama 5 tahun adalah 0.1. Hal ini sepertinya selaras dengan alasan berdirinya Bank Jabar Banten Syariah yang sesuai dengan slogan Provinsi Banten "Iman, Taqwa, dan Akhlaqul Karimah", serta sejalan dengan permintaan masyarakat Banten yang religius untuk menjalan aktifitas 
ekonomi secara syariah guna mewujudkan ajaran islam dalam kehidupan sehari-hari (Thohuri, 2020).

Objek selanjutnya adalah self (nafs) dimana rata-rata PI paling tinggi adalah 0,234 oleh Bank Syariah Mandiri. Terciptanya nilai yang tinggi pada objek ini tercermin dari setiap misi yang dibawa oleh Bank Syariah Mandiri dalam annual report nya, terutama pada tahun 2017 tema dari laporan tahunan BSM adalah "Tumbuh Sehat Berkelanjutan, Mengalirkan Berkah untuk Negeri". Tentu dengan menunjukan kinerja yang positif, bank dapat terus berkontribusi untuk mengalirkan berkah bagi seluruh umat dan membangun ekonomi.

BTPN Syariah pada objek intellect ('aql) mendapatkan poin paling tinggi dari rata-rata selama 5 tahun sebesar 0,0008218. Komisaris BTPN syariah Bapak Kemal Aziz Stamboel pada tahun 2018 menyatakan bahwa pengembangan bank dilakukan dengan cara yang unik pada model bisnis dan pengembangan Sumber Daya Manusia (SDM). Hal ini mencakup dilakukan penelitian secara berkelanjutan serta pelaksanaan aktivitas pemberdayaan. Melalui aspirasi dari para karyawan bank, diharapkan dapat mengubah paradigma sosial dan mengubah nasabah untuk dapat memperbaiki kualitas hidupnya.

Tabel 3. Kinerja IMSPM Bank Umum Syariah Tahun 2015-2019

\begin{tabular}{|c|c|c|c|c|c|c|}
\hline \multirow{2}{*}{ NAMA BANK } & \multicolumn{5}{|c|}{ TAHUN } & \multirow{2}{*}{$\begin{array}{l}\text { RATA } \\
\text { RATA }\end{array}$} \\
\hline & 2015 & 2016 & 2017 & 2018 & 2019 & \\
\hline PT. BANK MUAMALAT INDONESIA & 0.26 & 0.26 & 0.25 & 0.25 & 0.26 & 0.25 \\
\hline PT. BANK VICTORIA SYARIAH & 0.30 & 0.20 & 0.26 & 0.24 & 0.24 & 0.25 \\
\hline PT. BANK BRI SYARIAH & 0.26 & 0.26 & 0.24 & 0.26 & 0.23 & 0.25 \\
\hline PT. BANK JABAR BANTEN SYARIAH & 0.19 & 0.13 & 0.15 & 0.20 & 0.32 & 0.20 \\
\hline PT. BANK BNI SYARIAH & 0.27 & 0.28 & 0.27 & 0.28 & 0.29 & 0.28 \\
\hline PT. BANK SYARIAH MANDIRI & 0.89 & 0.28 & 0.34 & 0.24 & 0.24 & 0.40 \\
\hline PT. BANK MEGA SYARIAH & 0.29 & 0.23 & 0.22 & 0.28 & 0.24 & 0.25 \\
\hline PT. BANK PANIN SYARIAH & 0.34 & 0.29 & 0.07 & 0.24 & 0.25 & 0.24 \\
\hline PT. BANK SYARIAH BUKOPIN & 0.25 & 0.25 & 0.23 & 0.24 & 0.23 & 0.24 \\
\hline PT. BCA SYARIAH & 0.28 & 0.27 & 0.27 & 0.23 & 0.22 & 0.25 \\
\hline PT. BTPN SYARIAH & 0.23 & 0.22 & 0.22 & 0.25 & 0.32 & 0.26 \\
\hline
\end{tabular}

Sumber : Data diolah Peneliti (2020)

Rata-rata selama lima tahun untuk objek posterity (nasl) dengan perolehan nilai paling tinggi sebesar 0,0111 adalah Bank Mandiri Syariah. Pencapaian ini didapatkan dari komitmen yang dilakukan oleh BMS untuk mendukung pelaku agribisnis guna mendorong pertumbuhan ekonomi, BMS juga menyalurkan dana hibah bagi para petani melalui Program Desa Berdaya Sejahtera Mandiri. Objek terakhir adalah wealth (mal) yang 
berkaitan dengan aktivitas pendanaan dan kualitas manajemen, poin tertinggi diraih oleh BNI Syariah dengan perolehan nilai rata-rata selama lima tahun adalah 0,0616. Pelaksanaan pembiayaan baik mudharabah maupun musyarakah oleh BNI Syariah mencakup pelaku usaha UMKM di seluruh pelosok negeri

\section{Nilai Perusahaan}

Nilai perusahaan dalam penelitian diaproksimasikan pada nilai EVA. Perolehan nilai EVA dari setiap bank sepanjang lima tahun pengamatan ada yang bernilai positif dan negatif. Dari keseluruhan tahun, Bank Syariah Mandiri memperoleh nilai EVA paling tinggi sebesar 22.280.156 ribu pada tahun 2019 sedangkan bank dengan perolehan EVA terendah adalah Bank Syariah Bukopin pada tahun 2018 denga perolehan - 2.972.183. Rata-rata perolehan EVA sepanjang lima tahun pengamatan juga menunjukan bahwa Bank Syariah Mandiri memperoleh nilai EVA paling tinggi dengan 19.912.163 ribu, sedangkan untuk yang paling rendah dengan perolehan - 420.004 ribu adalah Bank Jabar Banten Syariah. Bank dengan EVA diatas 0 atau bernilai positif menunjukan adanya penciptaan nilai yang terjadi di tahun tersebut atau sepanjang lima tahun pengamatan untuk para stakerholder.

Dari hasil pengamatan selama lima tahun, dapat diambil kesimpulan bahwa tidak ada satu bank pun yang mengalami kenaikan atau penurunan EVA setiap tahunnya, semuanya sangat fluktuatif. Namun dengan rata-rata perolehan EVA dari 11 sampel, bank dengan nilai EVA yang tinggi cenderung mempunyai NOPAT yang positif dan stabil. Begitu pula dengan nilai IC yang tidak begitu fluktuatif dalam perubahan nilainya sepanjang 5 tahun bahkan cenderung naik seiring dengan bertambahnya tahun. Hal ini dibuktikan dengan 3 (tiga) bank dengan perolehan rata-rata EVA tertinggi yaitu Bank Syairah Mandiri, disusul Bank Mega Syariah, dan Bank BRI Syariah mengalami peningkatan dan penurunan NOPAT yang tidak begitu signifikan serta perolehan modal investasi yang cenderung naik setiap tahunnya. Tabel 4 menunjukkan hasil perhitungan EVA dari 11 sampel Bank Umum Syariah sepanjang 5 (lima) tahun pengamatan. Tabel 4 menunjukkan hasil perhitungan EVA dari 11 sampel Bank Umum Syariah sepanjang 5 (lima) tahun pengamatan. 
Rida Almiravalda Hidayat: Indeks Maqashid Syariah Dan Nilai Perusahaan

Tabel 4. Perhitungan EVA Bank Umum Syariah Tahun 2015-2019

\begin{tabular}{|c|c|c|c|c|c|c|}
\hline \multirow{2}{*}{ NAMA BANK } & \multicolumn{5}{|c|}{ TAHUN } & \multirow{2}{*}{$\begin{array}{l}\text { RATA- } \\
\text { RATA }\end{array}$} \\
\hline & 2015 & 2016 & 2017 & 2018 & 2019 & \\
\hline PT. BANK MUAMALAT INDONESIA & $6,493,666$ & $2,064,226$ & $8,170,015$ & 149,841 & $4,273,607$ & $4,230,271$ \\
\hline PT. BANK VICTORIA SYARIAH & $(40,225)$ & $(38,341)$ & 10,307 & 10,236 & 632 & $(11,478)$ \\
\hline PT. BANK BRI SYARIAH & $7,330,223$ & $8,390,367$ & $12,012,412$ & $14,830,201$ & $11,722,395$ & $10,857,120$ \\
\hline PT. BANK JABAR BANTEN SYARIAH & 133,844 & $(1,025,677)$ & $(1,303,496)$ & 40,927 & 54,380 & $(420,004)$ \\
\hline PT. BANK BNI SYARIAH & 345,494 & 324,347 & 291,957 & 455,038 & $1,846,583$ & 652,684 \\
\hline PT. BANK SYARIAH MANDIRI & $17,580,981$ & $19,922,473$ & $21,589,254$ & $18,187,950$ & $22,280,156$ & $19,912,163$ \\
\hline PT. BANK MEGA SYARIAH & $21,067,707$ & $12,144,687$ & $7,884,131$ & $7,105,372$ & $8,204,278$ & $11,281,235$ \\
\hline PT. BANK PANIN SYARIAH & $13,093,033$ & $15,433,332$ & 20,412 & 851,033 & $7,015,281$ & $7,282,618$ \\
\hline PT. BANK SYARIAH BUKOPIN & $3,558,528$ & $3,023,507$ & $(1,849,279)$ & $(2,972,183)$ & $1,006,543$ & 553,423 \\
\hline PT. BCA SYARIAH & $1,623,891$ & $1,540,775$ & $2,417,111$ & $3,231,711$ & $6,328,826$ & $3,028,463$ \\
\hline PT. BTPN SYARIAH & $19,475,503$ & $6,343,490$ & $2,975,819$ & $2,105,486$ & $2,043,323$ & $6,588,724$ \\
\hline
\end{tabular}

Sumber : Data diolah Peneliti (2020) 
Rida Almiravalda Hidayat: Indeks Maqashid Syariah Dan Nilai Perusahaan

\section{Struktur Modal}

Nilai struktur modal ditunjukkan dengan nilai CAR. Tabel 5 menunjukkan nilai CAR diperoleh dari laporan keuangan tahunan masingmasing bank selama lima tahun. Secara umum, nilai CAR setiap tauhunnya mengalami peningkatan seperti yang terjadi pada BTPN Syariah dan Bank Syariah Mandiri, namun ada juga bank yang mengalami penurunan seperti Bank Jabar Banten Syariah atau hampir merata seperti Bank Muamalat Indonesia.

Melihat hasil secara keseluruhan, perolehan CAR tertinggi diraih oleh Bank BTPN Syariah dengan nilai 0,45 atau 45\% pada tahun 2019 dan yang terendah sebesar 0,12 atau $12 \%$ oleh dua bank yaitu Bank Muamalat Indonesia di tahun 2015, 2018, dan 2019 serta Bank Panin Syariah pada tahun 2017. Secara rata-rata, bank dengan nilai CAR tertinggi adalah BCA Syariah sebesar 33\% diikuti oleh BTPN Syariah dengan 32\% sedangkan yang paling rendah adalah bank Muamalat Indonesia dengan 13\%.

Tabel 5. Capital Adequacy Ratio (CAR) Bank Umum Syariah Tahun 2015-2019

\begin{tabular}{lcccccc}
\hline \multicolumn{1}{c}{ NAMA BANK } & \multicolumn{5}{c}{ TAHUN } & $\begin{array}{c}\text { RATA- } \\
\text { RATA }\end{array}$ \\
\cline { 2 - 6 } PT. BANK MUAMALAT & $\mathbf{2 0 1 5}$ & $\mathbf{2 0 1 6}$ & $\mathbf{2 0 1 7}$ & $\mathbf{2 0 1 8}$ & $\mathbf{2 0 1 9}$ & 0.13 \\
\hline INDONESIA & 0.12 & 0.13 & 0.14 & 0.12 & 0.12 & 0.19 \\
\hline PT. BANK VICTORIA SYARIAH & 0.16 & 0.16 & 0.19 & 0.22 & 0.19 & 0.22 \\
\hline PT. BANK BRI SYARIAH & 0.14 & 0.21 & 0.20 & 0.30 & 0.25 & 0.18 \\
\hline PT. BANK JABAR BANTEN & & & & & & 0.18 \\
SYARIAH & 0.23 & 0.18 & 0.16 & 0.16 & 0.15 & 0.15 \\
\hline PT. BANK BNI SYARIAH & 0.15 & 0.15 & 0.20 & 0.19 & 0.20 & 0.18 \\
\hline PT. BANK SYARIAH MANDIRI & 0.13 & 0.14 & 0.16 & 0.16 & 0.16 & 0.15 \\
\hline PT. BANK MEGA SYARIAH & 0.19 & 0.24 & 0.22 & 0.21 & 0.20 & 0.21 \\
\hline PT. BANK PANIN SYARIAH & 0.20 & 0.18 & 0.12 & 0.23 & 0.14 & 0.18 \\
\hline PT. BANK SYARIAH BUKOPIN & 0.16 & 0.15 & 0.19 & 0.19 & 0.15 & 0.17 \\
\hline PT. BCA SYARIAH & 0.34 & 0.37 & 0.29 & 0.24 & 0.38 & 0.33 \\
\hline PT. BTPN SYARIAH & 0.20 & 0.24 & 0.29 & 0.41 & 0.45 & 0.32 \\
\hline Sumber : Data diolah Peneliti $(\mathbf{2 0 2 0 )}$ & & & & &
\end{tabular}

\section{Uji Regresi}

Regresi linier berganda digunakan untuk mengetahui pengaruh variabel independen terhadap variabel dependen dengan taraf signifikansi 5\%. Persamaan (4) menunjukkan hasil analisis regresi linier berganda pengaruh Indeks Maqashid Syariah dan Struktur Modal terhadap Nilai Perusahaan.

Nilai Perusahaan $(\mathrm{Y})=8696.64+2410.934$ Indeks Maqashid Syariah $(\mathrm{X} 1)$ 17310.9 Struktur Modal (X2) 
Rida Almiravalda Hidayat: Indeks Maqashid Syariah Dan Nilai Perusahaan

Tabel 6. Hasil Regresi Linier Berganda

\begin{tabular}{ccccc}
\hline Variabel & Koefisien & Error & t-Statistic & Prob \\
\hline Konstanta & 8696.64 & 3069.707 & 2.833052 & 0.0071 \\
\hline Indeks Maqashid Syariah & 2410.934 & 6360.232 & 0.379064 & 0.0076 \\
\hline Struktur Modal & -17310.9 & 12867.18 & -1.345353 & 0.1857 \\
\hline F-statistic & 10.50310 & R-squared & & 0.750055 \\
\hline Prob & 0.00000 & & & \\
\hline
\end{tabular}

Sumber : Data diolah Peneliti (2020)

\section{Pengaruh Indeks Maqashid Syariah terhadap Nilai Perusahaan}

Dari hasil pengujian regresi linier berganda koefisien Indeks Maqashid Syariah sebesar 2.410,934 dengan hasil positif, sehingga apabila Indeks Maqashid syariah meningkat 1 poin maka akan meningkatkan Nilai Perusahaan sebesar Rp 2.410,934 juta. Dari Tabel 6, nilai probabilitas koefisien Indeks Maqashid Syariah sebesar 0.0076 yang berarti probabilitas < 0.05 sehingga Indeks Maqashid Syariah berpengaruh signifikan terhadap Nilai Perusahaan. Sehingga dapat disimpulkan bahwa Indeks Maqashid Syariah berpengaruh positif signifikan terhadap Nilai Perusahaan, dengan demikian hipotesis diterima.

Dari hasil penelitian, perusahaan-perusahaan dengan Indeks Maqashid Syariah melalui nilai IMSPM yang lebih tinggi mempunyai nilai EVA sebagai indikator Nilai Perusahaan yang cenderung tinggi pula. Bank Syariah Mandiri mempunyai nilai IMSPM rata-rata tertinggi dari 11 sampel penelitian dengan 40\%, begitu juga dengan Nilai Perusahaan yang di ukur melalui EVA, ratarata tertinggi diraih oleh Bank Syariah Mandiri sebesar 19.912.163 ribu. Penggunaan IMSPM untuk mengukur kinerja perusahaan ternyata mempunyai fungsi yang sama dengan alat pengukur kinerja bank umum guna menentukan keberhasilan bank yang dapat di lihat melalui nilai perusahaannya. Hal ini sejalan dengan penelitian yang dilakukan Wahyuni et al. (2020) dimana Indeks Maqashid Syariah mempengaruhi naik turunnya nilai perusahaan perbankan syariah.

Dalam penelitian ini faktor intellect dalam IMSPM juga menempati posisi terendah dalam hasil perhitungan Indeks Maqashid Syariah seperti pada penelitian yang dilakukan Damayanti (2018), artinya sampai saat ini perusahaan belum berfokus pada pengembangan sumber daya manusia baik internal perusahaan maupun perhatian tentang pentingnya pendidikan di lingkungan sosial dan penelitian terutama terhadap pengembangan perbankan syariah. Namun begitu, dalam penelitian kali ini Indeks Maqashid Syariah sudah memberikan pengaruh yang signifikan terhadap Nilai perusahaan yang berarti adanya peningkatan kualitas pemahaman sumber daya manusia tentang perbankan syariah itu sendiri dan praktek 
pengembangan teknologi yang lebih meningkat menepis pernyataan yang disampaikan oleh (Rohmah et al., 2019).

Dapat disimpulkan penggunaan IMSPM sebagai alat ukur perbankan syariah lebih akurat dibandingkan dengan alat ukur sebelumnya karena penggabungan faktor financial dan non financial didalam penghitungan rasio performa sehingga dapat memberikan kontribusi yang lebih besar dalam meningkatnya Nilai Perusahaan.

\section{Pengaruh Struktur Modal terhadap Nilai Perusahaan}

Hasil analisis regresi linier berganda untuk Struktur Modal menunjukan nilai koefisien sebesar $-17.310,9$ dengan nilai negatif, sehingga apabila struktur modal meningkat 1 poin disini adalah 1\% akan menurunkan Nilai Perusahaan sebesar Rp 17.310,9 juta begitupula sebaliknya. Sedangkan untuk nilai probabilitas sesuai dengan hasil pada Tabel 6 sebesar 0,1857 yang berarti > dari level of significance sehingga tidak signifikan. Oleh karena itu dapat disimpulkan bahwa Struktur Modal berpengaruh negatif tidak signifikan terhadap Nilai Perusahaan.

Dalam penelitian yang dilakukan Rahayu, Suhadak, \& Saifi (2020), dinyatakan bahwa penggunaan hutang di dalam perusahaan meningkatkan nilai perusahaan karena dapat mengurangi pajak dan menurunkan bunga hutang perusahaan. Didalam perbankan syariah, tidak semua bank memberikan bagi hasil, ada beberapa bank yang memberikan bagi hasil di tahun tertentu namun tidak di tahun yang lain, tidak adanya bunga dan adanya zakat di dalam perbankan syariah mungkin menjadi faktor yang menjadi perbedaan dengan hasil penelitian terdahulu.

Sejalan dengan pernyataan yang disampaikan oleh Ogbulu \& Emeni (2012) tentang modal ekuitas sebagai bagian dari Struktur Modal tidak berpengaruh terhadap Nilai Perusahaan di negara berkembang. Hal ini karena keuntungan pembayaran pajak yang dikaitkan dengan adanya hubungan antara struktur modal terhadap nilai perusahaan dihadapkan dengan fakta bahwa pemegang saham membayar pajak lebih besar dibandingkan dengan pemegang obligasi.

Walaupun secara umum struktur modal yang di gambarkan melalui CAR pada perbankan syariah cenderung meningkat setiap tahunnya Richard (2020). Jika struktur modal tidak berpengaruh terhadap nilai perusahaan seperti hasil penelitian tentu bukan merupakan bahan pertimbangan yang baik untuk para investor. Hal ini karena para investor memberikan investasi dana dengan harapan memperoleh bagi hasil yang tinggi. Perolehan profit yang tinggi berkaitan cukup erat dengan Nilai Perusahaan, sehingga dalam memilih investasi pihak pemilik modal akan mencari faktor-faktor yang lebih berpengaruh terhadap penciptaan profit dan nilai dari perusahaan terkait. 
Dalam hal ini CAR mungkin belum dapat memproyeksikan struktur modal yang dimaksud dalam penelitian sebelumnya seperti Antwi et al. (2012) dan Ananda (2017) yang menyatakan bahwa struktur modal berpengaruh terhadap nilai perusahaan. Oleh karena itu, pihak perusahaan perbankan syariah butuh riset yang lebih dalam tentang penentuan struktur modal yang optimal agar tidak merugikan pihak investor, kreditur, dan perusahaan itu sendiri.

\section{KESIMPULAN}

Dari hasil pengamatan Indeks Maqashid Syariah menggunakan IMSPM, bank dengan laporan keuangan yang lebih lengkap cenderung memiliki IMSPM lebih baik. Hasil analisis menunjukan bahwa Indeks Maqashid Syariah berpengaruh positif signifikan terhadap Nilai Perusahaan. Hal ini ditunjukan dengan bank yang mempunyai nilai IMSPM tinggi cenderung mempunyai nilai EVA yang tinggi pula. Sedangkan pengujian terhadap Struktur Modal dan Nilai Perusahaan menunjukan hasil yang berbeda yaitu Struktur Modal tidak berpengaruh signifikan terhadap Nilai Perusahaan. Penggunaan IMSPM sebagai alat ukur Indeks Maqashid Syariah menunjukan bahwa perusahaan perlu menggunakan faktor keuangan dan syariah secara berdampingan di dalam mengukur performa perbankan syariah sehingga kedepanya BI dapat melakukan regulasi khusus terkait pengukuran kinerja bank syariah agar dapat lebih berkembang.

\section{DAFTAR PUSTAKA}

Analia, A. L., \& Anto, M. B. H. (2019). Performance Measurement of Islamic Banking in Indonesia Using the Maqashid Sharia index Method. Proceeding of Conference on Islamic Management Accounting and Economic, 2(1), 235-244.

Ananda, N. A. (2017). Pengaruh Profitabilitas Dan Struktur Modal Terhadap Nilai Perusahaan. Jurnal Ekonomi Dan Bisnis Indonesia, 2(1), 25-31. https://doi.org/10.37673/jebi.v2i1.50

Antonio, M. S., Sanrego, Y. D., \& Taufiq, M. (2012). An Analysis of Islamic Banking Performance: Maqashid Index Implementation in Indonesia and Jordania. Journal of Islamic Finance, 1(1), 12-29.

Antwi, S., Mills, E. F. E. A., \& Zhao, X. (2012). Capital Structure and Firm Value: Empirical Evidence from Ghana. Internatioanl Journal of Business and Social Sciense, 3(19), 252-261.

Efendi, A. F. W., \& Wibowo, S. S. A. (2017). Pengaruh debt to eqruity ratio (DER) dan debt to asset ratio (DAR) terhadap kinerja perusahaan di sektor keuangan yang terdaftar di bursa efek indonesia. Journal of Applied Managerial Accounting, 1(2), 157-163. 
Groth, C. J., \& Anderson, R. C. (1997). Capital Struture: Perspective for Managers. Management Decision, 35(7), 552-561.

Gupta, R., \& Gupta, B. M. (2014). Indian Lymphoma Research : A Scientometric Analysis of Indian Publications Output during 2004-13. Collnet Journal of Scientometrics and Information Management, 8(2), 419-436. https://doi.org/10.1080/09737766.2014.954866

Haniffa, R., \& Hudaib, M. (2007). Exploring the ethical identity of Islamic Banks via communication in annual reports. Journal of Business Ethics, 76(1), 97-116. https://doi.org/10.1007/s10551-006-9272-5

Harjito, A., \& Martono. (2012). Manajemen Keuangan Edisi Ke-2. Ekonosia.

Harris, M., \& Raviv, A. (1979). Optimal incentive contracts with imperfect information. Journal of Economic Theory, 20(2), 231-259. https://doi.org/10.1016/0022-0531(79)90073-5

Hidayat, R., Oktaviani, Y., \& Aminudin, A. (2019). Financial Performance of Islamic Banking in Indonesia With Maqasid Shariah Approach. Manajemen Bisnis, 9(1). https://doi.org/10.22219/jmb.v9i1.9442

Hudaefi, F. A., \& Noordin, K. (2019). Harmonizing and constructing an integrated maqāșid al-Sharī‘ah index for measuring the performance of Islamic banks. ISRA International Journal of Islamic Finance, 11(2), 282302. https://doi.org/10.1108/IJIF-01-2018-0003

Istiqamah, M., \& Supriyanto, N. (2017). Analisis Struktur Modal Perbangkan Syariah Di Indonesia Tahun 2011-2015. Jurnal Penelitian, 14(2), 201214. https://doi.org/10.28918/jupe.v14i2.979

Jauziyah, I. Q. (1973). ). I'lamul Muwaqqi'in 'an Rabbil Alamin Editor: Thaha Abdur Rauf Sa'd. Darul Jail.

Lestari, L. (2017). Pengaruh Kepemilikan Institusional Dan Struktur Modal Terhadap Nilai Perusahaan. Jurnal Riset Manajemen Dan Bisnis (JRMB) Fakultas Ekonomi UNIAT, 2(September), 293-306. https://doi.org/10.36226/jrmb.v2is1.62

Mifrahi, M. N., \& Fakhrunnas, F. (2018). Islamic Bank peformance based on Maqasid Based Performance Evaluation Model (MPEM). Jurnal Ekonomi \& Keuangan Islam, 4(2), 93-103.

https://doi.org/10.20885/jeki.vol4.iss2.art6

Modigliani, F., \& Miller, M. H. (1958). The Cost of Capital, Corporation Finance and the Theory of Investment. The American Economic Review, 48(3), 261-297.

Mohammed, M. O., Razak, D. A., \& Taib, F. M. (2008). The Performance Measures of Islamic Banking Based on the Maqashid Framework. IIUM International Accounting Conference (INTAC IV), IV, 2-5.

Mohammed, M. O., \& Taib, F. M. (2015). Developing Islamic Banking Performance Measures Based on Maqasid Al-Shari'Ah Framework: Cases of 24 Selected Banks. In Journal of Islamic Monetary Economics and Financem 1(1), 55-77). https://doi.org/10.21098/jimf.v1i1.483

Nizar, M. C. (2016). Literatur Kajian Maqashid Syariah Ulul Albab. Ulul Albab: Jurnal Studi Dan Penelitian Hukum Islam, 35, 53-68.

Ogbulu, O. M., \& Emeni, F. K. (2012). Capital Structure and Firm Value: Empirical Evidence from Nigeria. Internatioanl Journal of Business and 
Social Sciense, 3(19), 252-261.

Otoritas Jasa Keuangan. (2020). https://www.ojk.go.id/Pages/SPS Januari 2020

Padli, M. S., \& Diana, N. A. (2019). Pengaruh Good Corporate Governance, Maqashid Sharia, Dan Profitabilitas Terhadap Nilai Perusahaan (Studi Empiris Pada Bank Umum Syariah di Indonesia Periode 2012-2017). EJra, 8(1), 1-13.

Panigrahi, S. K. (2017). Economic Value Added and Traditional Accounting Measures for Shareholder's Wealth Creation. Asian Journal of Accounting and Governance, 8, 125-136. https://doi.org/10.17576/ajag-2017-08-11

Richard, R. (2020). Analisis Pengaruh Profitabilitas, Likuiditas dan Struktur Modal Terhadap Nilai Perusahaan Perbankan yang Terdaftar Di Bursa Efek Indonesia (BEI) Periode 2014-2018. Jurnal Manajemen Bisnis Dan Kewirausahaan, 4(6), 293. https://doi.org/10.24912/jmbk.v4i6.9796

Rohmah, J., Askandar, N. S., \& Malikah, A. (2019). Analisis Pengaruh Ukuran Perusahaan dan Kinerja Maqashid Syariah Index Terhadap Nilai Perusahaan (Studi Kasus Pada Bank Umum Syariah Tahun 2013-2017). E-Jra, 08(05), 44-55.

Rosanti, R. A. (2019). Telaah Kinerja Keuangan Perbankan Syariah Dengan Pendekatan Sharia Maqashid Index Di Indonesia. Prosiding Seminar Nasional \& Call For Paper, 10, 85.http://jurnal.unmuhjember.ac.id/ index.php/sncp/article/view/1996

Saifi, M., Suhadak, Rahayu, S. M., \& Handayan, S. R. (2020). The Effect of Corporate Governance and Investment Opportunity Set on Capital Structure, Dividend Policy, and Firm Performance (A Study on GoPublic Manufacturing Companies in Indonesia Stock Exchange). International Journal of Management and Administrative Sciences (IJMAS), 3(02), 53-63.

Silalahi, M., Komariyah, I., Sari, A. P., Purba, S., Sudirman, A., Nugraha, N. A., \& Sulasih, S. (2020). Dasar-Dasar Manajemen dan Bisnis. Yayasan Kita Menulis.

Srikandi, I.P. (2017). Analisis Preferensi Pedagang Pasar Tradisional terhadap Sumber Permodalan dalam Perspektif Ekonomi Islam. repository.radenintan.ac.id

Sriram, G. (1978). Working Capital. Chem Age India, 29(4), 245-251. https://doi.org/10.3390/encyclopedia1030058

Thohuri, R., (2020). Quodavis Bank Banten. https://tangerangexpose.com/ 2020/05/02/dr-rizqullah-thohuri-quovadis-bank-banten/

Khanh, V. T., Hung, D. N., Van, V. T. T., \& Huyen, H. T. (2020). A study on the effect of corporate governance and capital structure on firm value in vietnam. Accounting, 6(3), 221-230.https://doi.org/10.5267/ j.ac.2020.3.004

Wahyuni, S., Pujiharto, \& Hartikasari, A. I. (2020). Sharia Maqashid Index and Its Effect on The Value of The Firm of Islamic Commercial Bank in Indonesia. Jurnal Riset Akuntansi Dan Keuangan Indonesia, 5(1), 37-45. 